\title{
What Do the Members of A.C.R.L. Want?
}

$\mathrm{T}$ HE Association of College and Reference Libraries, at its Buffalo meeting, June 1946, instructed its Committee on the Relations of the A.C.R.L. to the A.L.A. to send to all A.C.R.L. members a request for a statement of preferences in regard to the activities which might well be performed by a national professional library association. The committee also attempted to obtain the opinion of members in regard to the location of a possible A.C.R.L. headquarters.

The responses to the requests indicated that a majority of the members of A.C.R.L. did not have enough information or enough interest to fill out the blanks. About onethird of the membership responded, and many statements were returned with a note that the signer had not sufficient information to fill out all answers intelligently. The returns, however, are worthy of study.

The requests were prepared after careful study and consideration by several members. Two comments almost immediately received were contradictory: the first, that the questionnaire was "loaded" from the standpoint of A.C.R.L.; the second, that the questionnaire was so worded as to favor A.L.A. Obviously, the reaction to the wording of the statement of preferences depended upon the point of view of the individual reader. The committee strove earnestly to make the questions as factual as possible.

\section{Location of A.C.R.L. Headquarters}

The answers to the questions in C-I of the request were the most clear-cut. These questions were intended to ascertain the opinions of members in regard to the location of A.C.R.L. headquarters. The returns indicated the expense in maintaining A.C.R.L. headquarters was the most influential factor in determining opinions.

In answering the question whether A.C.R.L. headquarters should be located at A.L.A. Headquarters or at some library apart from A.L.A. Headquarters provided the cost were the same, 273 members felt that it should be located at A.L.A. Headquarters and 270 expressed the opinion that it should be located elsewhere. Certainly this vote indicated no decided opinion on the part of the association. Ten members filing returns expressed no opinion.

The next question inquired whether A.C.R.L. headquarters should be located at A.L.A. Headquarters if the cost for maintenance were greater at A.L.A. Headquarters. The vote was as follows: 395 felt the office should be located elsewhere as against 136 members favoring A.L.A. Headquarters; 22 did not vote,

On the other hand, if the cost were greater at a headquarters apart from A.L.A. than at A.L.A. Headquarters, 334 favored location at A.L.A. Headquarters and 186 apart from A.L.A. Headquarters; 33 did not vote.

The expression of opinion in regard to the site of location of A.C.R.L. headquarters if it should be placed apart from A.L.A. was as follows:

360 at some university library center

102 independent of any educational institution 
23 at some reference library

20 at some college library

48 not voting

Three hundred two members of the association felt that headquarters should be located in Chicago; 167 , close to Chicago; 28, New York; 19, Washington; 12, at some other city; 25 indicated no preference.

\section{A.L.A. Bulletin or College and Research Libraries?}

To the next question, Section $\mathrm{C}-2$, the answers were decisive. The committee inquired whether members would prefer to receive as a partial return for their membership dues the A.L.A. Bulletin or College and Research Libraries. Four hundred twenty-two members stated they would prefer to receive College and Research $\mathrm{Li}$ braries, while one hundred three preferred to continue to receive the A.L.A. Bulletin. Nineteen voted that they wanted both publications; nine did not vote. Obviously a great majority of members of A.C.R.L. would prefer to have College and Research Libraries sent to them without additional payment rather than the A.L.A. Bulletin.

\section{What Type of Executive Office Do Mem- bers Want?}

The committee, at its June meeting, had some argument as to the kind of executive secretary A.C.R.L. needed. Since we wanted to work in a democratic fashion, we submitted the question to the members. In Section D we asked members to check one of the two following statements:

I. In theory I would prefer a high-powered executive secretary with as large a force as feasible to carry on the business of the association,

\section{OR}

2. I would prefer to see within the A.C.R.L. decentralization with more emphasis on the work to be done by officers and committees and with less work concentrated in headquarters, although a full-time paid executive secretary would be necessary to stimulate and coordinate the activities of committees.

The first question was checked by 147 and the second question by 392 . Fourteen did not vote. In view of discussions with individual members, correspondence, and statements submitted with the returns, the following interpretation may be justified. Apparently a majority of the members of the association believed much of the work of the association should be done through committees; they did not want a high-powered executive secretary who, as some expressed it, might be the "boss" of the association rather than its servant. Comments indicated that many members felt that the organization of the executive office should follow the example of S.L.A. and that the A.C.R.L. should rely chiefly on work of committees. Indeed, many members expressed the opinion that the S.L.A., as a functioning organization, had been much more successful than the A.L.A. in arousing interest and support. Some, especially those in scientific and technical libraries, thought that A.C.R.L. should combine with the college section of S.L.A. The executive secretary of A.C.R.L. should assist in the work of committees and should be able to recommend members who are able and willing to assist in performing some of the duties which devolve upon a national association. This assignment of work to committees implies an allocation of funds to committees which function. The office of the executive secretary should be in part a clearing house for the work of sections, boards, and committees.

\section{Activities of a National Organization}

Probably more important was the attempt of the committee to obtain the statement of the fields of professional activity 
which members felt were the most needed. Members were requested to rank ten different proposals in the order of their preferences. In the computation of the returns of Section B we have allowed ten points for each vote for first place, nine points for second place, etc. One point was allowed for tenth place. By this method of tabulation, the following results were obtained: perform certain functions. The table on the following page represents the opinions of members.

Seven members left this entire group blank. At least two conclusions can be drawn from that table. The members believed that there are many fields with which A.C.R.L. is primarily concerned and which require far-reaching efforts of an

\begin{tabular}{|c|c|c|}
\hline Points & $\begin{array}{l}\text { Not } \\
\text { Voting }\end{array}$ & Activity \\
\hline 3648 & 20 & Publications directly and chiefly concerning college and university libraries. \\
\hline 198 & 33 & $\begin{array}{l}\text { Research studies on the functions of college and university libraries, on } \\
\text { college library personnel, etc. }\end{array}$ \\
\hline $305 \mathrm{I}$ & 24 & $\begin{array}{l}\text { Development of relations with educational associations in the field of } \\
\text { higher education and development of contacts with college presidents, library } \\
\text { committees, and professors. }\end{array}$ \\
\hline 771 & 29 & Compilation of statistics on college, university, and reference libraries. \\
\hline 684 & 45 & Studies in the field of professional education for college li \\
\hline 2647 & 40 & Placement of college and university library personnel. \\
\hline 2246 & 48 & $\begin{array}{l}\text { Build up membership of A.C.R.L. by a publicity campaign and by work } \\
\text { with A.C.R.L. committee. }\end{array}$ \\
\hline 2214 & 37 & $\begin{array}{l}\text { Work with and stimulate committees of A.C.R.L. and A.L.A., insofar } \\
\text { as college activities are concerned, and with section leaders of A.C.R.L. to } \\
\text { increase their functioning. Coordinate the work of such committees. }\end{array}$ \\
\hline II 3 & 43 & $\begin{array}{l}\text { Expand College and Research Libraries and issue the periodical monthly } \\
\text { instead of quarterly. }\end{array}$ \\
\hline I727 & 43 & $\begin{array}{l}\text { Arrange for the executive secretary of A.C.R.L. to attend as many state } \\
\text { and regional meetings as reasonable and attempt to build up strong state } \\
\text { and regional organizations. }\end{array}$ \\
\hline
\end{tabular}

Forty members left this entire group blank. The members regarded as the foremost important activities: publications, research studies on the functions of college libraries, development of relations with educational associations, and statistics. Several comments were received expressing the belief that placement, ranked sixth, should be performed, not by national associations, but by personnel departments of library schools. It should be noted that activities ranked low on the list were not regarded necessarily as unimportant.

\section{Should A.L.A. or A.C.R.L. Function in Certain Described Areas?}

Finally, the committee attempted to ascertain whether A.L.A. or A.C.R.L. should executive secretary and committees of the association. Many members also believed that certain activities relating, at least in part, to college, university, and reference libraries must be performed jointly by A.L.A. and A.C.R.L. since many of these activities affect groups other than college and reference librarians. The writer would interpret the returns on this question as requiring close relations between A.C.R.L. and A.L.A., possibly even to location, on a trial basis, of headquarters of A.C.R.L. at A.L.A. Headquarters, unless other factors appear which may cause difficulties.

\section{Conclusions}

Certain conclusions may be summarized. First, the rank and file of members of 


\begin{tabular}{|c|c|c|c|c|}
\hline 1.C.R.L. & A.L.A. & Both & $\begin{array}{l}\text { Not } \\
\text { Voting }\end{array}$ & Function \\
\hline 487 & 7 & 50 & 2 & $\begin{array}{l}\text { Publications directly and chiefly concerning college } \\
\text { and university libraries. }\end{array}$ \\
\hline 5 & 274 & 260 & 7 & $\begin{array}{l}\text { Publications more general but with some relation } \\
\text { to college, university, and reference libraries; as, } \\
\text { for example, a' book on general library administra- } \\
\text { tion. }\end{array}$ \\
\hline 423 & $4 \mathrm{I}$ & 79 & 3 & $\begin{array}{l}\text { Compilation of statistics on college, university, and } \\
\text { reference libraries. (It is presupposed that the U.S. } \\
\text { Office of Education will not be able to publish these } \\
\text { statistics satisfactorily.) }\end{array}$ \\
\hline 193 & 77 & 267 & 9 & $\begin{array}{l}\text { Placement of college and university library per- } \\
\text { sonnel. (If you think placement service for college } \\
\text { librarians should be combined with placement service } \\
\text { for all types of librarians, answer this question by } \\
\text { "A.L.A." or "Both".) }\end{array}$ \\
\hline 507 & 2 & 34 & 3 & $\begin{array}{l}\text { Research studies on the functions of college and } \\
\text { university libraries, on college library personnel, etc. }\end{array}$ \\
\hline 397 & 20 & 121 & 8 & $\begin{array}{l}\text { Studies in the field of professional, education for } \\
\text { college library personnel. }\end{array}$ \\
\hline 410 & 15 & 112 & 9 & $\begin{array}{l}\text { Development of relations with educational asso- } \\
\text { ciations in the field of higher education and develop- } \\
\text { ment of contacts with college presidents, library } \\
\text { committees, and professors. }\end{array}$ \\
\hline 422 & 4 & 109 & II & $\begin{array}{l}\text { Build up membership of A.C.R.L. by a publicity } \\
\text { campaign and by work with A.C.R.L. committee. }\end{array}$ \\
\hline 158 & II & 349 & 28 & $\begin{array}{l}\text { Work with and stimulate committees of A.C.R.L. } \\
\text { and A.L.A., insofar as college activities are con- } \\
\text { cerned, and with section leaders of A.C.R.L. to } \\
\text { increase their functioning. Coordinate the work of } \\
\text { such committees. }\end{array}$ \\
\hline 204 & 60 & 272 & 10 & $\begin{array}{l}\text { International relations, as affecting colleges and } \\
\text { university libraries. }\end{array}$ \\
\hline
\end{tabular}

A.C.R.L. either were not interested in filling out the statement or did not have sufficient facts on which to base their opinions.

Second, a great majority would prefer to receive College and Research Libraries rather than the A.L.A. Bulletin as a partial return for their payment of dues.

Third, the functioning of a placement agency was not regarded as important as many of us had thought. On the other hand, publications, research studies, and statistics were rated high.

Fourth, the association prefers to work chiefly through committees with an executive office to serve as a clearing house.

The committee is grateful to the members of the association who filled out con- scientiously the statement of preferences and especially to those who sent in letters and comments and also to those who have spent considerable time in discussing with the chairman and other members of the committee the possible development of professional associations of librarians. The 553 members replying to the request have rendered a great service in giving a picture of their opinions. The number of replies was certainly sufficient to justify the conclusion that they represent the opinions of A.C.R.L. members. There is now no reason why the questions considered should be raised again for debate. 

mittee and Executive Board at Their September-October Meetings

The resolutions adopted by the Committee on the Relations of the A.C.R.L. to the A.L.A. but not presented to the association in June, the action by A.L.A. Council, by the Executive Board, and by A.C.R.L. at their June meetings were published in full in the Library Journal. ${ }^{1}$

At meetings held in September 1946 the special Committee on Relations of Divisions to the A.L.A. voted as follows:

I. That the A.L.A. should try to achieve such participation by all subject groups and geographic units as will enable each member to have, and to feel that he has, a share of responsibility for A.L.A. support, policies, and activities.

2. That the autonomy in matters affecting primarily their own members and institutions provided by the Constitution and By-Laws to divisions and, so far as possible to sections, should be made effective; and that additional efforts should be made to give divisions a proportionate share of responsibility for policy making and activities, including special projects, which affect them as well as other groups.

3. That machinery be provided which will enable the chapters, while retaining the autonomy they have always enjoyed, to have a large share in policy making and activities primarily in order that due consideration may be given to regional and state differences in library needs and possibilities.

4. That decisions as to what matters are of concern to the A.L.A., even while affecting interests of subject groups and chapters, must often be made by the A.L.A. Council for policy and the Executive Board for administration; and that these bodies should, therefore, be made as fully representative of all groups as possible.

5. That the Headquarters staff (wherever located) is to be considered as a secretariat for the Association as a whole; that its interests should be as wide as those of the whole Association including divisions, sections, round tables, chapters, boards, and committees; that, although perfect balance in emphasis in any one year is not to be expected, there should be

\footnotetext{
1 Library Journal 71:1005-10, August 1946.
}

reasonable distribution of emphasis in a decade.

6. That large divisions and other major interests should be represented by specialists; that each specialist should be responsible primarily to a board of directors of a division or, if there is no division in the special field, to an appropriate board or committee; that the work of each specialist should be so tied with the work of other specialists and with other activities of the Association as to enable all parts of the organization to derive some benefit and the Association as a whole to gain strength from the work of the specialist.

7. That efforts should be made continuously to increase the representative character of committees and boards as a means of facilitating participation of all groups in activities in which they are interested.

8. That A.L.A. and its constituent groups and other library organizations should provide for continuous study of their relations to each other, to the end that autonomy for special groups may be attained and solidarity achieved for the profession as a whole.

It was voted: That this committee recommends that the Fourth Activities Committee consider the possibility of a universal membership in local, state, and regional associations, and the A.L.A.

That, in view of the above recommendation and having in mind Recommendation $I$ of the A.C.R.L. committee (Exhibit B), this committee further recommends that the Fourth Activities Committee consider the division of membership dues between the A.L.A. and the divisions.

That, with reference to A.C.R.L. resolutions two and four (Exhibit B), this committee recommends to the Budget Committee, the Executive Board, and the Council, subject to approval by A.C.R.L.:

a. That funds be appropriated for a fulltime professional librarian to serve as executive secretary to the A.C.R.L. with secretarial assistance.

b. That the committee believes further study should be given to the question of allocating to certain divisions income from the endowment funds of the Association.

c. That the work of the A.C.R.L. executive secretary be supervised and controlled by 
A.C.R.L.; that he also serve as the college and reference specialist for the profession; that the Executive Board invite and urge A.C.R.L. to establish its office at À.L.A. Headquarters.

d. That this committee believes that further consideration should be given to the proposals regarding divisional control of dues, the allocation of endowment income to divisions, a possible federation of library associations, and related matters. It believes, however, that these matters are of such fundamental importance that they should receive longer-term consideration by the Fourth Activities Committee and, therefore, should not be considered at this time. It recommends, however, that this special committee on relations be continued and especially charged with the responsibility of reviewing the question of divisional relations with respect to such matters as must have immediate attention.

The Executive Board approved Recommendations $\mathrm{I}$ to 8 as presented by the special Committee on Relations of Divisions of the A.L.A. as noted above. Also, in substance, the resolutions in regard to universal membership and the reference to the Fourth Activities Committee of the resolutions in regard to distribution of dues were approved by the Executive Board. Resolutions b, c, and $\mathrm{d}$ of the special Committee on Relations of Divisions to the A.L.A. were approved. Recommendation by the Budget Committee providing for an allotment to A.C.R.L. for the office of executive secretary at an annual rate of $\$ 10,000$ was approved. The allotment of $\$ 6,667$ was made to take effect Jan. I, 1947, since A.C.R.L. could not arrange for the establishment of its office earlier. The budgetary year of A.L.A. commences September I and hence only two-thirds of the allotment would be needed for the first year.

The Executive Board also endorsed the recommendation of the special Committee on Relations of Divisions to the A.L.A. that A.C.R.L. be invited and urged to locate its headquarters at A.L.A. Headquarters.
The action by the Executive Board at its October meeting, together with action by Council and by the Budget Committee and special committee, indicated an understanding of the needs of A.C.R.L. The various resolutions endorse the principle of autonomy for divisions in the management of activities within their own fields. It was agreed that the final decision on the question of location of A.C.R.L. headquarters rested with A.C.R.L. No conditions were attached to the allotment of $\$ 6,667$ for the office of executive secretary of A.C.R.L.

The response of A.C.R.L. to this action cannot be immediately forthcoming. The writer believes that the proposals made by the Executive Board will satisfy the immediate needs of A.C.R.L. and that additional questions can be studied more at leisure. Naturally, the next year or two will be a period of experimentation. Certainly great progress has been made in finding a solution to such questions as the autonomy of divisions, the maintenance of adequate executive offices for divisions, and the field of relationships of A.L.A. and A.C.R.L. The Executive Board, the Budget Committee, and the special Committee on Relations of Divisions to the A.L.A. deserve credit for their consideration of the problem of A.C.R.L.

The officers and committees of A.C.R.L. now have an opportunity to concentrate efforts on the development of a strong organization which will contribute much to the future of college, university, and reference libraries. During the next few years this development will require much study and thought by the entire membership. The opportunity has been given us.

Future of A.L.A. and A.C.R.L.

The following considerations are the result of much correspondence and discussions with many librarians. The writer, how- 
ever, is solely responsible for the ideas expressed.

Future trends can at times be ascertained from a study of past events. The American Library Association in 1900 had 874 members. The Association of College and Reference Libraries now has over 1600 members; the A.L.A. membership has risen to about 16,000 . The A.L.A. had a fulltime paid Secretary in 1911 when its membership was 2,046, not much greater than the membership of A.C.R.L. today.

Although A.L.A. Headquarters has developed to a very great extent since 1920 , the organization of the Association shows little radical change in spite of the reports of three activities committees. The name of "sections" has been changed to "divisions," the number of sections has been greatly increased, but fundamentally the organization of A.L.A. remains about the same.

A new factor, however, has appeared in the organization of professional librarians. Before 1900 the A.L.A. could be said, with some accuracy, to represent the entire group of professional librarians within the United States. Before 1898 there existed apart from the A.L.A. only one national association of librarians, the National Association of State Libraries. Now, an examination of the list of national library associations in the A.L.A. Handbook, December 1945, indicates that there are today about fourteen national library associations, one of which, the Special Libraries Association, has a membership of about 4,300. Nine of these associations were founded since 1920 ; seven since 1930. The Council of National Library Associations was organized in 1942, partly to provide an organization which could represent all librarians and all types of libraries. Obviously with fourteen or fifteen separate library associations, the A.L.A. can no longer speak for all libraries and all librarians. The Council of $\mathrm{Na}$ tional Library Associations is not at present organized to permit adequate functioning as a body representing the entire library profession.

Is the present trend to continue? Are we to have an increasing number of national library associations representing special fields of activity or special groups? Can the A.L.A. become an organization which will enable it to represent all types of libraries and all librarians, or will the A.L.A. become simply one of many library associations?

These are the factors which influenced the A.C.R.L. committee to present proposals which would point the way to the development of the A.L.A. into a holding corporation. There are two options. The A.L.A. might combine with the Council of National Library Associations to form an overhead association which would include within its organization all specialized groups. Such an association would necessarily have far more authority than the present council. Dues would be collected by the member associations. A proportion of the dues would be transferred to the reorganized council after its consolidation with A.L.A. The member associations would have their own executive offices; certainly some of them would be at A.L.A. Headquarters, some would not. Even such organizations as the Association of Research Libraries could continue their unpaid secretaries with their headquarters wherever they might decide. The reorganized A.L.A., possibly with the subtitle Council of National Library Associations, could maintain its chief headquarters in Chicago, if it so desired, with branch headquarters in New York and Washington. Member associations might prefer to have their headquarters at the New York, Washington, or Chicago branches. Librarians 
would have only one bill a year for dues. The dues would be paid to member associations and a proportion, to be agreed upon later, would be transferred to A.L.A. to support activities which concern the profession as a whole or several member associations. The member associations would have complete autonomy on matters affecting primarily their own fields.

The second option, of course, is to continue as we are. We can then look forward to the creation of many more national library associations. Librarians and libraries will be requested to pay dues to many different associations. Even at present some of us are members of four or five national library associations. We shall have conflicts, overlapping activities, and eventually almost a chaos.

What are some of the advantages in the form of organization envisaged by the A.C.R.L. committee? Its proposals represent a decentralization of certain aspects of control and hence greater democracy. Some decentralization must be made if members are to retain their interest. More attention must be given to the consideration of the needs of minority groups. More attention must be given to opportunities for participation in our councils, discussions, and activities by the rank and file of our members.

These considerations apply not only to national associations but to state and regional organizations. Many comments were received listing the exclusion of any consideration of activities of special groups by our state associations. One member wrote at length that in his state the library association had never given attention to the needs of college librarians; not one cent had ever been appropriated for the state activities of the college and reference librarians' group. He added that the college librarians were considering the organization of a separate library association to unite with the S.L.A. group in that state.

In another state for 'seven consecutive years no college librarian had been a member of the executive board of the state library association. Indeed, during these seven years no one except a public librarian or a public library trustee was elected to the executive board of the state association. At times college librarians in this state have had separate meetings apart from the state library association. One leader in this state remarked publicly that district meetings were not intended for college librarians. Too often our state library associations are maintained for and by the public library group. Minority groups of college, school, and special libraries are not considered a functioning part of the state association.

These statements do not apply to all regional and state library associations. They do apply to many and they show the difficulties in any organization with minority groups unless autonomy and participation in control and activities can be arranged for such groups. The Pacific Northwest Library Association is an excellent example of an organization which provides for the activities of minorities.

In view of this condition, the remarks by certain A.L.A. committee members deserve consideration. In connection with universal membership, it was proposed that the various divisions of A.L.A. collect their own dues independently and receive no allotment from A.L.A. Universal membership would not apply to group associations. The A.L.A. would become a national association with regional, state, and city branches. The payment of one membership fee would entitle a member to belong to a local, state, regional, and one national association (A.L.A.), but not to any association which might represent his special interests, such as A.C.R.L. This proposal would leave (Continued on page 43) 
ample, discovered the library to be a place of inspiration and enchantment. They were, they found, the latest in a devoted band of men and women who for upwards of two and one-half centuries have brought to Yale the materials of -scholarship which a university must have if it is to fulfill its high purpose.

This convocation signalizes one moment in that endless expression of aspiration and faith. Yale has been happiest when the collector, the custodian, and the scholar have been in harmony. These three are rarely met in one person, but such a man, Mr. President, comes before you now, applauded by his old students and colleagues and the friends of libraries and museums and of learning wherever they may be found.

Six other curators or directors of museums were also awarded honorary degrees.
The Yale Collections by Wilmarth S. Lewis $^{1}$ is a book which highlights all that was said and done at the ceremonies we have described, and its accounts of Yale's possessions in books, manuscripts, paintings, silver, furniture, textiles, ancient art, natural history, and anthropology are sufficient to drive anyone in a less-favored institution into a state of quiet despair. There are chapters on the library, the art gallery, the Peabody Museum of Natural History, and the anthropological museum, in which the history and development of each is traced and some account is given of the more notable of the individual collections acquired by gift or purchase by which they have been built up.

${ }^{1}$ New Haven, Conn., Yale University Press, 1946.

\section{What Do the Members of A.C.R.L. Want?}

\section{(Continued from page 10)}

the minority groups in even a worse position than at present. The question would legitimately be raised, why should any group such as the A.C.R.L. remain within the A.L.A. if it is to collect its own dues irrespective of A.L.A.? It would be far better to have an association of college, university, and reference librarians with its own branches in the various states uniting with other groups in the state for action on state and local affairs. If the proposal for universal membership mentioned above should become a reality, the strangle hold upon the minority groups would become complete. The only solution in such a case would seem to be to build up an organization for the larger minority groups similar to that of S.L.A.

All members of the A.C.R.L. committee want a strong national association representing the entire library profession but with autonomy for special groups in the management of their own affairs and with the privilege of deciding upon the general activities of value to their groups. This is democracy. The original proposals were designed to point the way for the formation of a strong national association representing all special groups. Eyen the proposal to form in six months a separate association of college and university librarians unless the A.L.A. was willing to discuss the proposals of the committee was made with the idea as expressed by one member that "temporary separation from the A.L.A. may be the most satisfactory method of bringing to the attention of A.L.A. the need for a radical change in the national organizations of libraries and librarians." The committee believed that the development of a strong national association as a holding corporation in the autonomy for special groups, with decentralized control, with a much greater participation by a much larger proportion of the membership is necessary for the successfull advancement of librarianship in the U.S. 